DOI: $10.15193 / \mathrm{zntj} / 2019 / 119 / 285$

\title{
HALINA MAKAŁA \\ WPLYW ŻYWIENIA KURCZĄT BROJLERÓW PASZĄ Z DODATKIEM NASION LNU I BEZ ICH UDZIAŁU NA WYBRANE WYRÓŻNIKI JAKOŚCI MIĘSA I TLUSZCZU
}

\begin{abstract}
Streszczenie
Celem pracy była ocena wpływu żywienia kurcząt brojlerów paszą bez dodatku nasion lnu i z ich udziałem na wybrane wyróżniki jakości mięsa i thuszczu drobiowego. Materiał doświadczalny stanowiły kurczęta brojlery Ross 308. Kurczęta zostały losowo podzielone na dwie grupy. Jedna była żywiona paszą bez dodatku ześrutowanych nasion lnu, a druga - z ich udziałem. Ocena surowca drobiowego obejmowała: uzyski masy ciała badanych kurcząt w grupie kontrolnej i doświadczalnej po zakończeniu odchowu, analizę rzeźną, wartości pH mięśni udowych i piersiowych, charakterystykę wyróżników barwy mięśni piersiowych i udowych kurcząt w systemie CIE L*a*b*, oznaczenie zawartości podstawowych składników chemicznych, takich jak: woda, białka, tłuszcze, związki mineralne w postaci popiołu i kolagen, ocenę wartości żywieniowej na podstawie profilu lipidowego mięśni piersiowych i udowych oraz skór, tłuszczu podskórnego i sadełkowego. W wyniku przeprowadzonych doświadczeń stwierdzono, że nasiona lnu stosowane w żywieniu kurcząt brojlerów nie miały wpływu w zwiększenie przyrostu masy ciała, masy mięśni piersiowych i udowych w tuszce. Zaobserwowano wpływ żywienia nasionami lnu na wzrost zawartości białka i zmniejszenie zawartości tłuszczu w mięśniach piersiowych i udowych. Stwierdzono korzystny wpływ zastosowania w żywieniu kurcząt brojlerów paszy zawierającej ześrutowane nasiona lnu na wartość żywieniową surowca i poprawę profilu lipidowego, szczególnie proporcje z dwukrotnie korzystniejszym wskaźnikiem PUFA $n$-6/PUFA $n-3$ oraz na większą zawartość KT z grupy PUFA $n$-3. Mięso z kurcząt wzbogacone w kwasy tłuszczowe z rodziny $n-3$ może być polecane jako źródło wzbogacające dietę ludzi w te kwasy, czyli jako żywność funkcjonalną.
\end{abstract}

Słowa kluczowe: brojlery kurcząt, nasiona lnu, wzbogacanie paszy, wyróżniki jakości mięsa i tłuszczu

\section{Wprowadzenie}

Mięso drobiowe jest cenione przez konsumentów ze względu na pożądaną wartość odżywczą oraz walory sensoryczne. Jest ono przede wszystkim dobrym źródłem białka o dużej wartości odżywczej. W porównaniu z innymi gatunkami mięsa jest ła-

Dr inż. H. Makała, Instytut Biotechnologii Przemystu Rolno-Spożywczego im. W. Dąrowskiego w Warszawie, ul. Rakowiecka 36, 02-532 Warszawa. Kontakt: halina.makala@ibprs.pl 
twostrawne, zawiera więcej pełnowartościowego białka oraz dzięki mniejszej ilości thuszczu charakteryzuje się mniejszą wartością energetyczną [5, 22, 24, 28, 39].

Z uwagi na szeroką dostępność i powszechność spożycia mięsa drobiowego poszukuje się rozwiązań mających na celu uzyskanie surowca o wyższej wartości żywieniowej. Efekt ten może być osiągnięty poprzez stosowanie dobranych ras i linii hodowlanych, wykorzystywanie w żywieniu brojlerów pasz bez dodatku antybiotykowych stymulatorów wzrostu lub zawierających składniki istotne żywieniowo [11, 20, 28, 37]. Wśród tych składników znaczącą rolę przypisuje się kwasom tłuszczowym z rodziny $n-3[15,21,23]$. Wpływ dodatku do paszy kurcząt brojlerów mieszanek wielonienasyconych kwasów tłuszczowych na jakość mięsa drobiowego był przedmiotem badań prowadzonych m.in. przez Osek i wsp. [34, 35, 36], Milczarek i wsp. [29, 30], Janochę i Milczarek [19]. Kwasy te mają istotne znaczenie dla prawidłowego wzrostu i rozwoju organizmu ludzkiego. Współczesna dieta jest deficytowa w kwasy tłuszczowe z grupy $n$-3 i charakteryzuje się bardzo szerokim stosunkiem kwasów n-6 do $n$-3, (od $15: 1$ do $25: 1)$, podczas gdy optymalny udział tych kwasów powinien wynosić $1: 1[25,27$, 51].

Modyfikację składu kwasów tłuszczowych w paszy dla kurcząt brojlerów można uzyskać poprzez dodatek do niej olejów roślinnych (lub nasion surowców oleistych), szczególnie tych, które zawierają długołańcuchowe kwasy tłuszczowe [2, 3, 17, 19]. Do takich olejów należą lniany i sojowy, przy czym najzasobniejszy w pożądane wielonienasycone kwasy thuszczowe, a zwłaszcza w kwas $\alpha$-linolenowy (C18:3, $n$-3), jest olej lniany. Kwas ten jest prekursorem kwasów eikozapentaenowego (EPA - C20:5) i dokozaheksaenowego (DHA - C20:6), które są niezbędne do prawidłowego przebiegu metabolizmu człowieka $[6,9,10]$. Proporcje kwasów $n-6$ do $n-3$ w oleju lnianym są korzystniejsze $(1: 0,5)$ niż w oleju sojowym $(10: 1)$, chociaż ten drugi jest najczęściej używany do natłuszczania mieszanek paszowych dla drobiu [18, 27, 30, 34]. Wzbogacenie diety kurcząt brojlerów w PUFA $n-3$ skutkuje zwiększeniem zawartości tych kwasów w ich mięsie i thuszczu $[24,54,55]$. Uzyskana w ten sposób poprawa wartości żywieniowej surowca drobiowego zwiększa jednak podatność tłuszczów na utlenianie w trakcie przechowywania $[12,13,18,32]$ i powstawanie szkodliwych dla organizmu wolnych rodników [4, 31].

Celem pracy była ocena wpływu żywienia kurcząt brojlerów paszą bez dodatku ześrutowanych nasion lnu i z ich udziałem na wybrane wyróżniki jakości mięsa i tłuszczu.

\section{Material i metody badań}

Materiał doświadczalny stanowiły kurczęta brojlery Ross 308. Pochodziły one $\mathrm{z}$ doświadczeń hodowlanych, które prowadzono w hali odchowu kurnika. Kurczęta zostały losowo podzielone na dwie grupy po 40 szt.: kontrolną $(\mathrm{K})$ i doświadczalną 
(D). Ptaki były chowane w osobnych przedziałach. Każdą grupę podzielono losowo na 4 podgrupy (po 10 szt. każda) stanowiące powtórzenia doświadczalne. Odchów trwał 39 dni. Kurczęta w obu grupach żywiono mieszankami dla brojlerów kurzych: do 21 . dnia życia starterem $(21,99$ \% białka ogółem i $2990 \mathrm{kcal} \mathrm{EM} / \mathrm{kg})$, a następnie do 38. dnia życia finiszerem (18,51 \% białka ogółem i 3217 kcal EM/kg). Mieszanki, którymi skarmiano brojlery $\mathrm{w}$ grupie doświadczalnej zawierały ześrutowane nasiona lnu w ilości $7 \%$. W 39. dniu życia kurczęta zostały pozbawione paszy, następnego dnia zostały zważone i ubite. Rozbiór tuszek i analizę rzeźną wykonywano po ok. $20 \mathrm{~h}$ chłodzenia [41].

Ocena surowca drobiowego obejmowała:

- uzyski masy ciała badanych kurcząt w grupie kontrolnej (K) i doświadczalnej (D) po zakończeniu odchowu (39 dni),

- analizę rzeźną kurcząt kontrolnych i doświadczalnych obejmującą wartości masy ciała, masy ciała tuszki bez podrobów, procentowy udział podrobów, mięśni piersiowych i mięśni udowych,

- ocenę wartości pH mięśni udowych i piersiowych mierzoną 24 h od uboju,

- charakterystykę wyróżników barwy mięśni piersiowych (MP) i udowych (MU) kurcząt kontrolnych i doświadczalnych w systemie CIE L*a*b*, którą wykonywano przy użyciu spektrofotometru Minolta (Konica Minolta Inc., Japonia),

- oznaczenie zawartości podstawowych składników chemicznych: wody (W) - metodą wagową po suszeniu według PN-ISO 1442:2000 [42], białka ogółem (B) metodą Kjeldahla przy użyciu aparatu Kjeltec Analyzer 1026 (FOSS Polska Sp. z o.o.) według PN-EN ISO 8968-1:2014-03 [45], tłuszczu (T) - metodą Soxhleta (metoda wagowa, ekstrakcja techniką Soxhleta) przy użyciu aparatu Soxtec Fat Analyzer HT-6 (FOSS Polska Sp. z o.o.) według PN-ISO 1444:2000 [43], składników mineralnych w postaci popiołu całkowitego - metodą wagową po spopieleniu według PN-ISO 936:2000 [44] oraz kolagenu - metodą spektrofotometryczną według PN-ISO 3496:2000 [46],

- ocenę wartości żywieniowej na podstawie profilu kwasów tłuszczowych, które oznaczano metodą chromatografii gazowej według PN-EN ISO 12966-2:2017-05 [47] przy użyciu chromatografu HP 6890 (Hewlett-Packard, USA) wyposażonego $\mathrm{w}$ detektor płomieniowo-jonizacyjny, kolumnę wysokopolarną z fazą BPX 70 o długości $60 \mathrm{~m}$, grubości filmu $0,25 \mu \mathrm{m}$ i średnicy wewnętrznej $0,25 \mathrm{~mm}$. Analiza przebiegała $\mathrm{W}$ programowanej temperaturze (temperatura początkowa $130{ }^{\circ} \mathrm{C}-$ 1 min, przyrost temperatury $1,5^{\circ} \mathrm{C}$ na min, temperatura końcowa $210{ }^{\circ} \mathrm{C}-7 \mathrm{~min}$, temperatura dozownika $220 \div 240^{\circ} \mathrm{C}$ ). Całkowity czas analizy wynosił ok. $40 \mathrm{~min}$. Wyniki analizy były automatycznie wyliczane według zasady wewnętrznej normalizacji za pomocą oprogramowania ChemStation wersja A 03.34® 1989-1994. Oceniano profil lipidowy mięśni piersiowych i udowych oraz skór i tłuszczu sadeł- 
kowego. Na podstawie składu kwasów tłuszczowych wyliczano wskaźnik ryzyka miażdżycy IA [7, 52].

Uzyskane wyniki poddano ocenie statystycznej w programie Statistca 6.0 PL. W celu określenia zróżnicowania próbek zastosowano jednoczynnikową analizę wariancji. Istotność różnic między wartościami średnimi oznaczonych parametrów weryfikowano testem Tukeya $(\mathrm{p} \leq 0,05)$.

\section{Wyniki i dyskusja}

Kurczęta rzeźne wyróżnia zdolność do szybkiego tempa wzrostu i dobrego wykorzystania paszy. Pełne wykorzystanie potencjału genetycznego kurcząt brojlerów wymaga stosowania $\mathrm{w}$ ich żywieniu mieszanek paszowych o dużej koncentracji energii, białka i pozostałych składników pokarmowych. Intensywny sposób żywienia zapewnia szybkie tempo wzrostu, dobre wykorzystanie paszy, zdrowotność, małe otłuszczenie oraz dobrą jakość i przydatność technologiczną pozyskiwanego mięsa [14, 34].

Analizę rzeźną kurcząt z uwzględnieniem takich czynników zmienności, jak: sposób żywienia (kurczęta kontrolne, w których żywieniu stosowano paszę standardową i kurczęta doświadczalne, w których żywieniu stosowano paszę zawierającą ześrutowane nasiona lnu) oraz płeć kurcząt (kurki, kogutki) przedstawiono w tab. 1. Średnia masa ciała kurcząt, masa tuszek oraz masa mięśni piersiowych i udowych wariantu kontrolnego była wyższa niż wariantu doświadczalnego, w których żywieniu zastosowano paszę z dodatkiem nasion lnu. Różnice te nie były statystycznie istotne. Wyższa masa ciała, wydajność rzeźna, masa mięśni piersiowych i udowych charakteryzowała osobniki męskie, niezależnie od sposobu żywienia.

Wydajność rzeźna kurcząt brojlerów wariantu kontrolnego ( $\mathrm{z}$ większą masą ciała) była statystycznie istotnie wyższa niż wariantu doświadczalnego (z mniejszą masą ciała). Podobne wyniki przedstawiły Michalczuk i Siennicka [28]. Wynika z nich, że kurczęta o większej masie ciała przed ubojem charakteryzowały się również większą wydajnością rzeźną [28]. Żywienie kurcząt ześrutowanymi nasionami lnu miało statystycznie istotny wpływ na zmniejszenie wydajności rzeźnej oraz wzrost udziału mięśni piersiowych w tuszce. Zastosowanie ześrutowanego siemienia lnianego w żywieniu nie wpłynęło na zwiększenie masy ciała oraz masę mięśni piersiowych i udowych w tuszce.

Wartości pH mięśni piersiowych i udowych mierzone $24 \mathrm{~h}$ od uboju zestawiono w tab. 2. Niezależnie od paszy stosowanej w żywieniu kurcząt średnie wartości $\mathrm{pH}$ mięśni piersiowych, zarówno w grupie doświadczalnej, jak i kontrolnej wynosiły 5,8, zaś pH mięśni udowych, także niezależnie od stosowanej paszy, w obu grupach osiągnęło wartość 6,2. Płeć badanych brojlerów również nie miała statystycznie istotnego wpływu na wartości pH zarówno mięśni piersiowych, jak i udowych. Wyższe wartości 


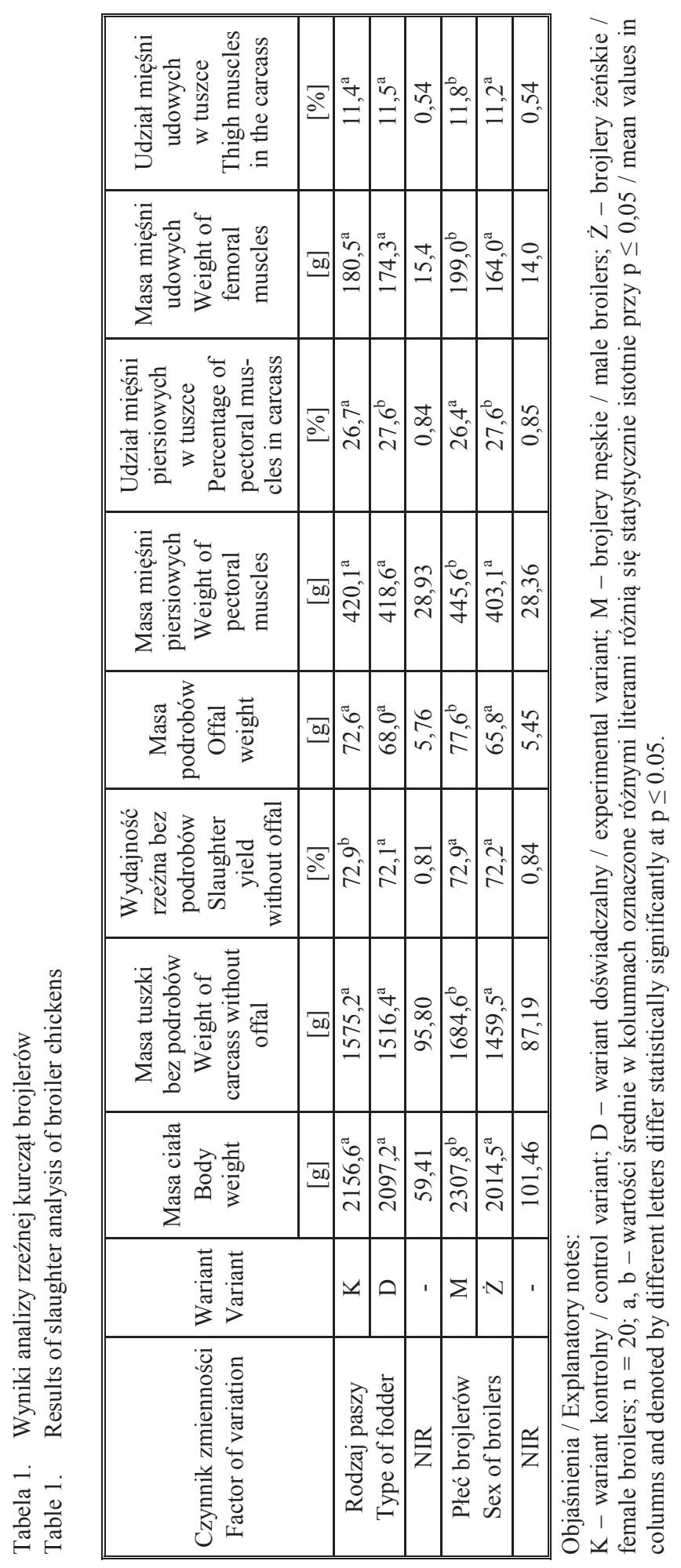


pH mięśni udowych niż piersiowych wykazane również m.in. w pracach Pietrzak i wsp. [37], Osek i wsp. [36], Kirschek i wsp. [24], Milczarek i wsp. [30] stwarzają korzystne warunki rozwoju bakterii, co wpływa na skrócenie dopuszczalnego czasu przechowywania [14].

Tabela 2. Charakterystyka wartości pH mięśni piersiowych (MP) i udowych (MU) kurcząt brojlerów mierzonych $24 \mathrm{~h}$ od uboju

Table 2. Characteristic of $\mathrm{pH}$ values of breast (BM) and femoral (FM) muscles of broiler chickens measured 24 hours after slaughter

\begin{tabular}{||c|c|c|c||}
\hline $\begin{array}{c}\text { Czynnik zmienności } \\
\text { Factor of variation }\end{array}$ & $\begin{array}{c}\text { Wariant } \\
\text { Variant }\end{array}$ & $\begin{array}{c}\mathrm{pH} \text { mięśni piersiowych } \\
\mathrm{pH} \text { of breast muscles }\end{array}$ & $\begin{array}{c}\mathrm{pH} \text { mięśni udowych } \\
\mathrm{pH} \text { of femoral muscles }\end{array}$ \\
\hline $\begin{array}{c}\text { Rodzaj paszy } \\
\text { Type of fodder }\end{array}$ & $\mathrm{K}$ & $5,8^{\mathrm{a}}$ & $6,2^{\mathrm{a}}$ \\
\cline { 2 - 4 } & $\mathrm{D}$ & $5,8^{\mathrm{a}}$ & $6,2^{\mathrm{a}}$ \\
\hline NIR & - & 0,01 & 0,01 \\
\hline $\begin{array}{c}\text { Płeć brojlerów } \\
\text { Sex of broilers }\end{array}$ & $\mathrm{M}$ & $5,8^{\mathrm{a}}$ & $6,2^{\mathrm{a}}$ \\
\cline { 2 - 4 } & $\dot{\mathrm{Z}}$ & $5,9^{\mathrm{a}}$ & $6,2^{\mathrm{a}}$ \\
\hline NIR & - & 0,04 & 0,08 \\
\hline
\end{tabular}

Objaśnienia jak pod tab. 1. / Explanatory notes as in Tab. 1.

Do wyróżników jakości mięsa mających istotny wpływ na jego zakup przez konsumenta należy barwa. Na jej podstawie dokonywana jest ocena świeżości i jakości surowca mięsnego, w tym sposób żywienia zwierząt czy system utrzymania [1, 18, 55]. Zdanowska-Sąsiadek i wsp. [53] podają, że polscy konsumenci preferują tuszki o naturalnie żółtym kolorze skóry, który utożsamiają z ekstensywnym systemem chowu i „naturalnym” żywieniem. Wśród czynników kształtujących barwę mięsa wymienia się płeć, wiek, genotyp, procesy przetwarzania, oświetlenie czy mrożenie. Mają one wpływ na zawartość mioglobiny i produktów jej przemian, co z kolei jest determinantą barwy mięsa [54]. Charakterystykę składowych barwy mięśni piersiowych (MP) i udowych (MU): L*, a*i b* badanych kurcząt brojlerów przedstawiono w tab. 3.

Na podstawie uzyskanych wyników stwierdzono, że wartości składowych barwy a* oraz b* mięśni udowych były statystycznie istotnie wyższe niż mięśni piersiowych, niezależnie od rodzaju stosowanej paszy jak i płci brojlerów, zaś jasność mięśni piersiowych $\mathrm{L}^{*}$ była statystycznie istotnie wyższa niż mięśni udowych, bez względu na rodzaj stosowanej paszy i płeć brojlerów. Wartości parametrów barwy L*, a* oraz b* w doświadczalnych mięśniach udowych były wyższe niż w mięśniach udowych kurcząt kontrolnych, choć obserwowane różnice nie były statystycznie istotnie. Wyższe wartości składowych parametrów barwy mięśni piersiowych stwierdzono w przypadku kogutków, choć obserwowane różnice nie były statystycznie istotnie. 
Tabela 3. Charakterystyka składowych barwy mięsni piersiowych (MP) i udowych (MU) kurcząt brojlerów

Table 3. Characteristic of colour components of breast (BM) and femoral (FM) muscles of broiler chickens

\begin{tabular}{||c|c|c|c|c|c|c|c||}
\hline \multirow{2}{*}{$\begin{array}{c}\text { Czynnik zmienności } \\
\text { Factor of variation }\end{array}$} & \multirow{2}{*}{$\begin{array}{c}\text { Wariant } \\
\text { Variant }\end{array}$} & \multicolumn{3}{|c|}{$\begin{array}{c}\text { Mięśnie piersiowe (MP) } \\
\text { Breast muscles }(B M)\end{array}$} & \multicolumn{3}{|c|}{$\begin{array}{c}\text { Mięśnie udowe (MU) } \\
\text { Femoral muscles (FM) }\end{array}$} \\
\cline { 3 - 8 } & & $\mathrm{L}^{*}$ & $\mathrm{a}^{*}$ & $\mathrm{~b}^{*}$ & $\mathrm{~L}^{*}$ & $\mathrm{a}^{*}$ & $\mathrm{~b}^{*}$ \\
\hline $\begin{array}{c}\text { Rodzaj paszy } \\
\text { Type of fodder }\end{array}$ & $\mathrm{K}$ & $48,7^{\mathrm{aB}}$ & $0,74^{\mathrm{aA}}$ & $4,53^{\mathrm{aA}}$ & $47,3^{\mathrm{aA}}$ & $6,16^{\mathrm{aB}}$ & $6,56^{\mathrm{aB}}$ \\
\cline { 2 - 8 } & $\mathrm{D}$ & $49,3^{\mathrm{aB}}$ & $0,46^{\mathrm{aA}}$ & $3,83^{\mathrm{aA}}$ & $48,2^{\mathrm{aA}}$ & $6,69^{\mathrm{aB}}$ & $7,14^{\mathrm{aB}}$ \\
\hline NIR & - & 0,55 & 0,28 & 0,71 & 0,83 & 0,53 & 0,58 \\
\hline $\begin{array}{c}\text { Płeć brojlerów } \\
\text { Sex of broilers }\end{array}$ & $\mathrm{M}$ & $49,8^{\mathrm{aB}}$ & $0,69^{\mathrm{aA}}$ & $4,30^{\mathrm{aA}}$ & $48,7^{\mathrm{aA}}$ & $6,25^{\mathrm{aB}}$ & $6,73^{\mathrm{aB}}$ \\
\cline { 2 - 8 } & $\dot{\mathrm{Z}}$ & $48,4^{\mathrm{aB}}$ & $0,53^{\mathrm{aA}}$ & $4,09^{\mathrm{aA}}$ & $47,0^{\mathrm{aA}}$ & $6,56^{\mathrm{aB}}$ & $6,95^{\mathrm{aB}}$ \\
\hline NIR & - & 1,37 & 0,16 & 0,21 & 1,70 & 0,30 & 0,22 \\
\hline
\end{tabular}

Objaśnienia jak pod tab. 1. / Explanatory notes as in Tab. 1.

Z uwagi na niedobory spożycia kwasów tłuszczowych z rodziny $n-3 \mathrm{w}$ diecie i ich rolę $\mathrm{w}$ prawidłowym metabolizmie organizmu ludzkiego istotne jest zwiększenie ich udziału w surowcach i przetworach mięsnych, w tym drobiowych, z uwagi na powszechną ich konsumpcję. Producenci mięsa zwierząt rzeźnych i drobiu oferują do sprzedaży surowce o wysokich walorach odżywczych i dietetycznych, których jakość uzależniona jest głównie od ilości i jakości tłuszczu [16, 20, 50, 53]. Wyniki podstawowego składu mięśni piersiowych oraz mięśni udowych badanych kurcząt przedstawiono w tab. 4 i 5.

Tabela 4. Wyniki podstawowego składu chemicznego mięśni piersiowych (MP) kurcząt brojlerów Table 4. Results of basic chemical composition of breast muscles (BM) of broiler chickens

\begin{tabular}{||c|c|c|c|c|c|c||}
\hline \hline $\begin{array}{c}\text { Czynnik } \\
\text { zmienności } \\
\begin{array}{c}\text { Factor of } \\
\text { variation }\end{array}\end{array}$ & Wariant & $\begin{array}{c}\text { Zawartość } \\
\text { Vody } \\
\text { Water } \\
\text { content }\end{array}$ & $\begin{array}{c}\text { Zawartość } \\
\text { białka } \\
\text { Protein } \\
\text { content }\end{array}$ & $\begin{array}{c}\text { Zawartość } \\
\text { tłuszczu } \\
\text { Fat } \\
\text { content }\end{array}$ & $\begin{array}{c}\text { Zawartość zw. miner. } \\
\text { jako popiół / Content of } \\
\text { mineral compounds in } \\
\text { the form of ash }\end{array}$ & $\begin{array}{c}\text { Zawartość } \\
\text { kolagenu } \\
\text { Collagen } \\
\text { content }\end{array}$ \\
\cline { 2 - 7 }$\left[\begin{array}{c}{[\%]} \\
{[\%]}\end{array}\right.$ & {$[\%]$} & {$[\%]$} & {$[\%]$} \\
\hline $\begin{array}{c}\text { Rodzaj paszy } \\
\text { Type of fodder }\end{array}$ & $\mathrm{K}$ & $74,5^{\mathrm{a}}$ & $22,8^{\mathrm{a}}$ & $1,3^{\mathrm{a}}$ & $1,2^{\mathrm{a}}$ & $0,46^{\mathrm{b}}$ \\
\hline & $\mathrm{D}$ & $75,5^{\mathrm{a}}$ & $23,3^{\mathrm{a}}$ & $1,0^{\mathrm{a}}$ & $1,2^{\mathrm{a}}$ & $0,37^{\mathrm{a}}$ \\
\hline NIR & - & 1,15 & 1,41 & 0,50 & 0,09 & 0,06 \\
\hline $\begin{array}{c}\text { Płeć brojlerów } \\
\text { Sex of broilers }\end{array}$ & $\mathrm{M}$ & $74,8^{\mathrm{a}}$ & $22,4^{\mathrm{a}}$ & $1,3^{\mathrm{a}}$ & $1,2^{\mathrm{a}}$ & $0,43^{\mathrm{a}}$ \\
\hline & $\dot{\mathrm{Z}}$ & $74,3^{\mathrm{a}}$ & $23,3^{\mathrm{a}}$ & $1,0^{\mathrm{a}}$ & $1,2^{\mathrm{a}}$ & $0,41^{\mathrm{a}}$ \\
\hline NIR & - & 1,20 & 1,47 & 0,54 & 0,10 & 0,08 \\
\hline \hline
\end{tabular}

Objaśnienia / Explanatory notes:

$\mathrm{K}$ - wariant kontrolny / control variant; $\mathrm{D}$ - wariant doświadczalny / experimental variant; $\mathrm{n}=8 ; \mathrm{a}, \mathrm{b}-$ wartości średnie w kolumnach oznaczone różnymi literami różnią się statystycznie istotnie przy $\mathrm{p} \leq 0,05$ / mean values in columns and denoted by different letters differ statistically significantly $p \leq 0.05$. 
Tabela 5. Wyniki podstawowego składu chemicznego mięśni udowych (MU) kurcząt brojlerów Table 5. Results of the basic chemical composition of femoral muscles (FM) of broiler chickens

\begin{tabular}{|c|c|c|c|c|c|c||}
\hline $\begin{array}{c}\text { Czynnik } \\
\text { zmienności } \\
\begin{array}{c}\text { Factor of varia- } \\
\text { tion }\end{array}\end{array}$ & Wariant & $\begin{array}{c}\text { Zawartość } \\
\text { Wody } \\
\text { Water } \\
\text { content }\end{array}$ & $\begin{array}{c}\text { Zawartość } \\
\text { białka } \\
\text { Protein } \\
\text { content }\end{array}$ & $\begin{array}{c}\text { Zawartość } \\
\text { tluszczu } \\
\text { Fat content }\end{array}$ & $\begin{array}{c}\text { Zawartość zw. miner. } \\
\text { jako popiół / Content of } \\
\text { mineral compounds in } \\
\text { the form of ash }\end{array}$ & $\begin{array}{c}\text { Zawartość } \\
\text { kolagenu } \\
\text { Collagen } \\
\text { content }\end{array}$ \\
\cline { 2 - 7 }$[\%]$ & {$[\%]$} & {$[\%]$} & $1 \%]$ & {$[\%]$} \\
\hline $\begin{array}{c}\text { Rodzaj paszy } \\
\text { Type of fodder }\end{array}$ & $\mathrm{K}$ & $71,9^{\mathrm{a}}$ & $19,1^{\mathrm{a}}$ & $7,1^{\mathrm{a}}$ & $1,0^{\mathrm{a}}$ & $0,78^{\mathrm{a}}$ \\
\cline { 2 - 7 } & $\mathrm{D}$ & $72,0^{\mathrm{a}}$ & $19,2^{\mathrm{a}}$ & $7,0^{\mathrm{a}}$ & $1,0^{\mathrm{a}}$ & $0,78^{\mathrm{a}}$ \\
\hline NIR & - & 1,88 & 1,87 & 1,94 & 0,06 & 0,14 \\
\hline $\begin{array}{c}\text { Płeć brojlerów } \\
\text { Sex of broilers }\end{array}$ & $\mathrm{M}$ & $71,5^{\mathrm{a}}$ & $18,1^{\mathrm{a}}$ & $8,3^{\mathrm{b}}$ & $1,0^{\mathrm{a}}$ & $0,82^{\mathrm{a}}$ \\
\hline & $\dot{\mathrm{Z}}$ & $72,2^{\mathrm{a}}$ & $19,7^{\mathrm{a}}$ & $6,4^{\mathrm{a}}$ & $1,1^{\mathrm{a}}$ & $0,74^{\mathrm{a}}$ \\
\hline NIR & - & 1,97 & 1,86 & 1,87 & 0,06 & 0,14 \\
\hline \hline
\end{tabular}

Objaśnienia jak pod tab. 4. / Explanatory notes as in Tab. 4.

Mięśnie piersiowe i mięśnie udowe brojlerów charakteryzowały się zmiennością wynikającą ze sposobu żywienia oraz płci. Rodzaj podawanej paszy, jak i płeć brojlerów nie miały statystycznie istotnego wpływu na podstawowy skład chemiczny surowca drobiowego, czyli na: zawartość wody, białka, tłuszczu i składników mineralnych w postaci popiołu, zarówno w grupie mięśni piersiowych, jak i udowych. Orkusz [33] podaje, że mięśnie piersiowe i udowe kurcząt brojlerów są surowcem o odmiennej charakterystyce składu podstawowego. Mięśnie piersiowe odznaczają się mniejszą zawartością tłuszczu i kolagenu, zaś większą - białka w porównaniu z mięśniami udowymi, co wskazuje na ich wysoką wartość dietetyczną [22, 33].

Zastosowanie w żywieniu kurcząt brojlerów paszy zawierającej ześrutowane nasiona lnu wpłynęło na wzrost zawartości białka i zmniejszenie zawartości tłuszczu zarówno w mięśniach piersiowych, jak i udowych, choć zależności te nie były statystycznie istotne. Uzyskane wyniki są porównywalne z wynikami badań przedstawionymi w pracach innych badaczy, w których średnia zawartość białka w mięśniach piersiowych wynosiła $22,9 \div 24,0 \%$, a w mięśniach udowych $19,2 \div 20,10 \%$, natomiast zawartość tłuszczu surowego $\mathrm{w}$ mięśniach piersiowych wynosiła 1,05 $\div 1,75 \%$, a w mięśniach udowych $-4,83 \div 5,46 \%[28,31,32,41]$.

Konsumenci mając do dyspozycji szeroką ofertę mięsa drobiowego w coraz większym stopniu zwracają uwagę na jego jakość. Wzrasta zainteresowanie mięsem kurcząt z wolnego wybiegu, jak również wzbogaconym w pożądane kwasy thuszczowe, zwłaszcza kwas oleinowy i linolenowy, które mają wpływ m.in. na obniżenie poziomu cholesterolu w osoczu krwi ludzi [28]. Simopoulos [49] wskazuje na zalety spożycia kwasów tłuszczowych w diecie człowieka, tj. zapobieganie i wspomaganie leczenia schorzeń układu krążenia, w tym głównie choroby wieńcowej, udaru mózgu, nadci- 
śnienia tętniczego oraz arytmii serca. Podobne obserwacje opisują inni badacze [21, $32,48,52]$.

Skład kwasów tłuszczowych zależy głównie od gatunku ptaków i może ulec zmianie w zależności od składu paszy. Drób może syntetyzować nasycone i monoenowe kwasy tłuszczowe z pasz nietłuszczowych. Są to głównie kwasy: palmitynowy i stearynowy oraz palmitooleinowy i oleinowy. Natomiast kwasy polienowe, jak linolowy (n- 6$)$ oraz linolenowy ( $n-3)$ nie są syntetyzowane przez drób i muszą być dostarczone ptakom w paszy $[28,35]$. W lipidach kurcząt oraz indyków udział kwasów tłuszczowych z rodziny $n-6$ oraz $n-3$ są zbliżone do wartości obecnie zalecanych w żywieniu ludzi [23, 38, 40].

Profil lipidowy mięśni piersiowych i udowych badanego surowca drobiowego przedstawiono $\mathrm{w}$ tab. $6 \mathrm{i}$ 7. W doświadczalnych mięśniach piersiowych stwierdzono większą zawartość KT z rodziny PUFA $n-3$ oraz dwukrotnie korzystniejsze proporcje PUFA n-6/PUFA $n$-3 niż w mięśniach kontrolnych. Podobne zależności wykazano w mięśniach udowych. Mięśnie piersiowe i udowe osobników męskich charakteryzowały się statystycznie istotnie większą zawartością KT MUFA w porównaniu z osobnikami żeńskimi.

Profil lipidowy skór i tłuszczu kurcząt kontrolnych i doświadczalnych przedstawiono w tab. 8. Korzystniejszy profil lipidowy stwierdzono w próbach doświadczalnych, charakteryzujących się dwukrotnie wyższym wskaźnikiem PUFA n-6/PUFA $n$-3 oraz większą zawartością KT z grupy PUFA $n$-3. Mieszanki, którymi skarmiano brojlery $\mathrm{w}$ grupie doświadczalnej, zawierające ześrutowane nasiona lnu, miały istotny wpływ na poprawę profilu lipidowego surowca drobiowego - mięśni piersiowych, udowych oraz skór i tłuszczu sadełkowego.

Kostecka i Łobacz [23] podają, że wprowadzenie do paszy dla drobiu nasion lub mączek z roślin oleistych albo odpowiednio dobranych olejów roślinnych skutkuje w znacznym stopniu zwiększeniem udziału kwasów polienowych w surowcu mięsnym, w szczególności kwasów z rodziny $n-3$ [2, 3, 23]. Skład oraz profil istotnych żywieniowo kwasów tłuszczowych tuszek kurcząt może być zatem zmodyfikowany poprzez odpowiednio dobrane thuszcze podawane w mieszankach paszowych. Uzyskane w ten sposób mięso brojlerów zostaje naturalnie wzbogacone w kwasy tłuszczowe z rodziny n-3 i zyskuje cechy żywności funkcjonalnej [8, 49, 51].

Zastosowanie w żywieniu kurcząt brojlerów paszy zawierającej ześrutowane nasiona lnu wpłynęło na zwiększenie wartości żywieniowej surowca w zakresie wzrostu zawartości białka, zmniejszenia zawartości tłuszczu oraz poprawy profilu lipidowego mięśni piersiowych i udowych w porównaniu z próbą kontrolną. Równocześnie wystąpiły korzystne zmiany wskaźnika ryzyka miażdżycy w mięśniach piersiowych kurcząt 


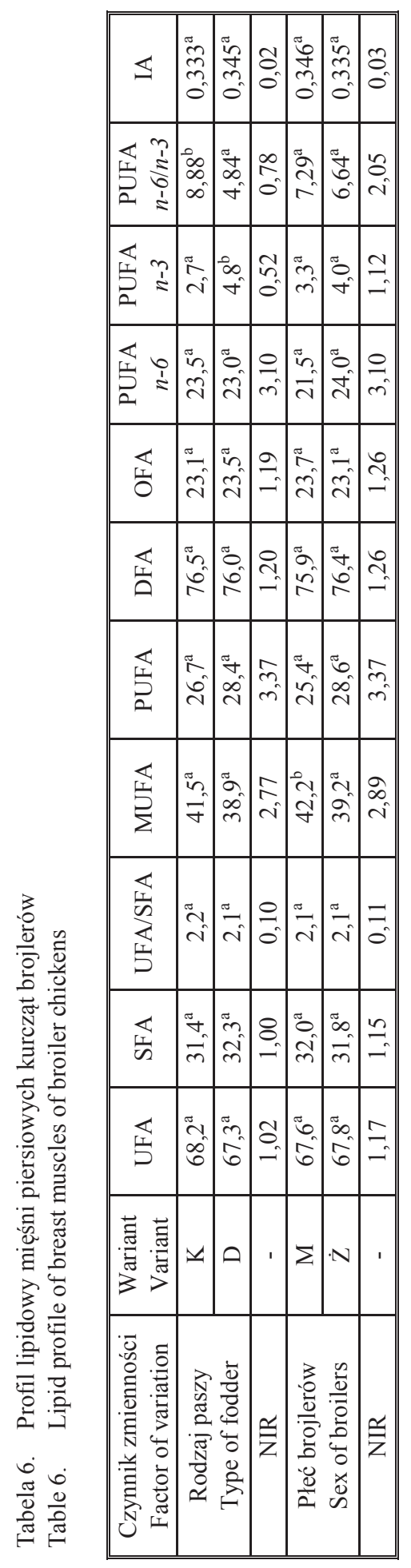

\begin{tabular}{|c|c|c|c|c|c|}
\hline 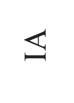 & 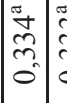 & 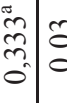 & & 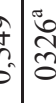 & 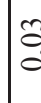 \\
\hline 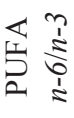 & 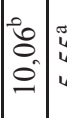 & $\begin{array}{l}n \\
n^{n} \\
n^{2}\end{array}$ & & $\begin{array}{lll}0 & \tilde{0} \\
0 & 0\end{array}$ & ले \\
\hline 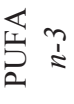 & 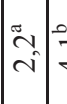 & 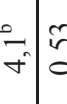 & & $\begin{array}{ll}0 \\
i & \stackrel{n}{n}\end{array}$ & \& \\
\hline 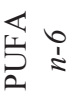 & 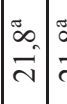 & 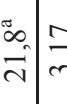 & & 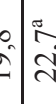 & $\bar{c}$ \\
\hline$\underset{\square}{\mathbb{5}}$ & 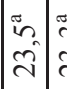 & 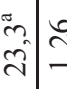 & & \begin{tabular}{l|l}
$n$ \\
$\hat{t}$
\end{tabular} & 2 \\
\hline 壳 & 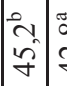 & 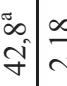 & & فـ & $\stackrel{\alpha}{\partial}$ \\
\hline 质 & 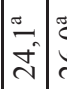 & 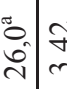 & & & $\stackrel{\overbrace{}}{c}$ \\
\hline$\underset{\Sigma}{\overleftrightarrow{\Sigma}}$ & 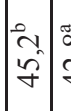 & 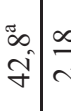 & & \begin{tabular}{l|l}
$f$ \\
$f$ \\
$f$
\end{tabular} & $\approx$ \\
\hline 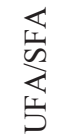 & $\mid \begin{array}{c}\tilde{m} \\
\tilde{i} \\
\end{array}$ & & & 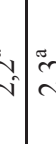 & $\frac{7}{c}$ \\
\hline 崩 & $\mid \begin{array}{l}\mid \\
\tilde{m} \\
\tilde{m} \\
\tilde{m}\end{array}$ & 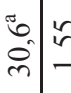 & & $=$ & Is \\
\hline$\overleftrightarrow{\Delta}$ & $\begin{array}{l}m \\
\tilde{m} \\
\tilde{b}\end{array}$ & 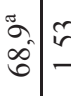 & & $\begin{array}{llll}0 \\
0 \\
0\end{array}$ & 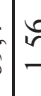 \\
\hline 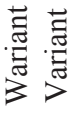 & $\triangle 6$ & ( & & $\Sigma \mid \lambda$ & \\
\hline 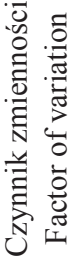 & 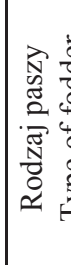 & 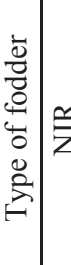 & & $\begin{array}{l}0 \\
0 \\
0 \\
0 \\
0 \\
0 \\
0 \\
0\end{array}$ & 刍 \\
\hline
\end{tabular}




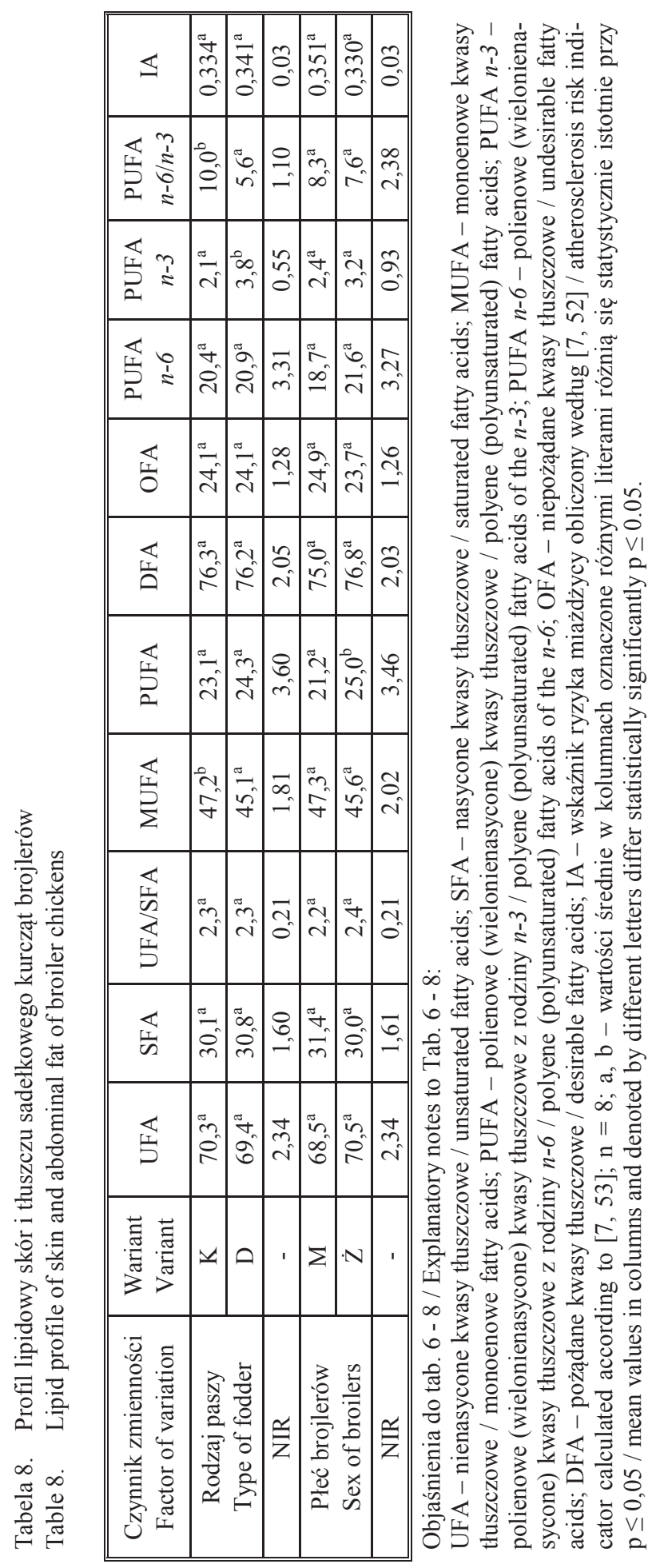


brojlerów, zwiększając prozdrowotne właściwości mięsa. Wysoka wartość dietetyczna, szczególnie mięśni piersiowych oraz zalety wynikające ze spożycia pożądanych kwasów thuszczowych z rodziny $n-3$ przesądzają o tym, że mięso kurcząt brojlerów tak karmionych może być polecane jako żywność funkcjonalna.

\section{Wnioski}

1. Nasiona lnu stosowane w żywieniu kurcząt brojlerów nie miały wpływu na zwiększenie przyrostu masy ciała, masy mięśni piersiowych i udowych w tuszce.

2. W wyniku zastosowania $\mathrm{w}$ żywieniu brojlerów paszy zawierającej ześrutowane nasiona lnu zaobserwowano tendencję wzrostu zawartości białka i zmniejszenia zawartości tłuszczu w mięśniach piersiowych i udowych.

3. Stwierdzono korzystny wpływ zastosowania w żywieniu kurcząt brojlerów paszy zawierającej ześrutowane nasiona lnu na wartość żywieniową surowca i poprawę profilu lipidowego, szczególnie proporcje z dwukrotnie korzystniejszym wskaźnikiem PUFA $n$-6/PUFA $n$-3 oraz większą zawartością KT z grupy PUFA $n$-3.

4. Nasiona lnu zastosowane $\mathrm{w}$ żywieniu drobiu powodują korzystne zmiany wskaźnika ryzyka miażdżycy w mięśniach piersiowych kurcząt brojlerów zwiększjące prozdrowotne właściwości mięsa.

5. Mięso z kurcząt brojlerów wzbogacone w kwasy thuszczowe $\mathrm{z}$ rodziny $n-3$ może być polecane jako żywność funkcjonalna.

\section{Literatura}

[1] Ahadi F., Chekani-Azar S., Shahryar H., Lotfi A., Mansoub N., Bahrami Y.: Effect of dietary supplementation with fish oil with selenium or vitamin $\mathrm{E}$ on oxidative stability and consumer acceptability of broilers meat. Global Vet., 2010, 4, 216-221.

[2] Al-Khalifa H.: Production of added-value poultry meat: Enrichment with $n-3$ polyunsaturated fatty acids. World's Poultry Sci. J., 2015, 71 (2), 319-326.

[3] Al-Khalifa H.: Enrichment of poultry diets with Polyunsaturated Fatty Acids (PUFA) for human consumption. Appro. Poult. Dairy Vet. Sci., 2017, 1 (5), \#APDV.000523.

[4] Alves A.B., Bragagnolo N., da Silva M.G., Skibsted L.H., Orlien V.: Antioxidant protection of highpressure processed minced chicken meat by industrial tomato products. Food Bioprod. Proc., 2012, 90 (3), 499-505.

[5] Augustyńska-Prejsnar A., Sokołowicz Z.: Czynniki kształtujące jakość sensoryczną mięsa kurcząt brojlerów. Wiad. Zoot., 2014, LII (2), 108-116.

[6] Bartnikowska E.: Fizjologiczne działania polienowych kwasów tłuszczowych z rodziny $n$-3. Tł. Jad., 2008, 43 (1/2), 10-15.

[7] Borys B., Borys A., Grześkiewicz S., Grześkowiak E.: Profil lipidowy oraz zawartość witaminy E w mięsie jagniąt tuczonych makuchem rzepakowym i nasionami lnu bez lub z suplementacją witaminy E - mięso surowe i po obróbce cieplnej. Rocz. IPMiTł., 2009, XLVII (2), 26-41. 
[8] Botez E., Nistor O.V., Andronoiu D.G., Mocanu G.D., Ghinea I.O.: Meat product reformulation: Nutritional benefits and effects on human health. In.: Functional Food - Improve Health Through Adequate Food. Eds. M.Ch. Hueda. IntechOpen, London 2017, pp. 167-184.

[9] Clarke S.D.: The multi-dimensional regulation of gene expression by fatty acids: Polyunsaturated fats as nutrients sensors. Curr. Opin. Lipidol., 2004, 15, 13-18.

[10] Gunstone F.D.: Vegetable oils. In: Bailey's Industrial Oil and Fat Products. Vol. 1: Edible Oil and Fat Products: Chemistry, Properties, and Health Effects. Ed. F. Shahidi. John Wiley \& Sons, Hoboken, New Jersey, 2005, pp. 213-267.

[11] Górska M., Wojtysiak D.: Wpływ długoterminowych czynników przyżyciowych na jakość sensoryczną mięsa drobiu grzebiącego. Wiad. Zoot., 2016, LIV (2), 171-176.

[12] Farrell D.: The role of poultry in human nutrition. Poultry Development Review, 2010. [on line]. FAO. Dostęp w Internecie [20.05.2018]: http://www.fao.org

[13] Farrell D.: The role of poultry in human nutrition. Poultry Development Review, FAO, Rome 2013, $1-10$.

[14] Gilewski R., Janocha A., Wężyk S., Zawiślak J.: Brojlery kurze - kulinarne mięso z piersi kurcząt brojlerów. Krajowa Rada Drobiarstwa - Izba Gospodarcza, Warszawa 2012.

[15] Grashorn M.A.: Research into poultry meat quality. Brit. Poultry Sci., 2010, 51 (3), 60-67.

[16] Grześkowiak E., Zając T., Borzuta K., Zając P., Tratwał Z., Lisiak D., Strzelecki J.: Badania wpływu dodatku do paszy świń preparatu z oleju z nasion lnu na wartość rzeźną tusz oraz jakość mięsa i tłuszczu. Rocz. IPMiTł., 2008, XLVI (2), 7-20.

[17] Holman R.T.: Omega-3 and omega-6 essential fatty acid status in human health and disease. In.: Handbook of Essential Fatty Acid Biology: Biochemistry, Physiology, and Behavioral Neurobiology. Eds. S. Yehuda and D.I. Mostofsky. Humana Press Inc., Totowa, New Jersey, USA, 1997, pp. 139-182.

[18] Hrastar R., Cheng L.Z., Xu X., Miller R.L., Kosir I.J.: Camelina sativa oil deodorization: Balance between free fatty acids and colour reduction and isomerized byproducts formation. J. Am. Oil Chem. Soc., 2011, 88, 581-588.

[19] Janocha A., Milczarek A.: Wpływ diety złożonej z surowców roślinnych na wydajność rzeźną i profil kwasów tłuszczowych mięsa kurcząt brojlerów. Rocz. IPMiTł, 2006, XIV (1), 71-79.

[20] Kiczorowska B., Samolińska W., Al-Yasiry A., Winiarska-Mieczan A., Kwiecień M.: Wartość odżywcza mięsa drobiowego pochodzącego z produkcji konwencjonalnej i ekologicznej. Probl. Hig. Epidemiol., 2015, 96 (3), 598-602.

[21] Kitajka K., Sinclair A.J., Weisinger R.S., Weisinger H.S., Mathai M., Jayasooriya A.P.: Effect of dietary omega-3 polyunsaturated fatty acids on brain gene expression. Proc. Natl. Acad. Sci. USA 2004, 101, 10931-10936.

[22] Konieczny P., Górecka D.: Mięso w żywieniu człowieka - aktualne kierunki w produkcji wyrobów mięsnych. Przem. Spoż., 2011, 3 (65), 28-31.

[23] Kostecka M., Łobacz M.: Lipidy mięsa kurzego - tłuszcz nie(d)oceniony. Cz. I. Charakterystyka thuszczu kurzego i wybrane metody modyfikacji. Post. Tech. Przetw. Spoż., 2009, 1, 98-103.

[24] Krischek C., Janisch S., Gunther R., Wicke M.: Nutrient composition if broiler and turkey breast meat in relation to age, gender and genetic line of the animals. J. Food Safety Food Quality, 2011, 3 (62), 73-104

[25] Leung I.Y.F., Sandstrom M.M., Zucker C.L., Neuringer M., Snodderly M.D.: Nutritional manipulation of primate retinas. IV. Effects of n-3 fatty acids, lutein and zeaxantin on S-conesand rods in the foveal region. Exp. Eye Res., 2005. 81 (5), 513-529.

[26] Makała H.: Effect of enriching model meat products with oils, abundant in polyunsaturated fatty acids on the selected quality parameters. EJPAU, 2007, 10 (2), \#15. 
[27] Maszewska M., Gańko I.: Kwasy tłuszczowe omega-3. Rola w żywieniu, występowanie, zastosowanie. Przem. Spoż., 2010, 64 (5), 28-31.

[28] Michalczuk M., Siennicka A.: Właściwości dietetyczne mięsa różnych gatunków drobiu utrzymywanych w alternatywnych systemach chowu. Przegl. Hod., 2010, 11, 26-30.

[29] Milczarek A., Osek M., Turyk Z., Janocha A.: Wpływ czasu przechowywania na skład chemiczny mięsa kurcząt brojlerów żywionych mieszankami natłuszczonymi olejem lnianym i zawierającymi różne dawki witaminy E. Rośliny Oleiste, 2011, XXXII, 127-136.

[30] Milczarek A., Osek M., Olkowski B., Klocek B.: Porównanie składu chemicznego świeżych i zamrażalniczo przechowywanych mięśni kurcząt brojlerów żywionych mieszankami paszowymi z różną ilością oleju sojowego, lnianego i witaminy E. Żywność. Nauka. Technologia. Jakość, 2013, 1 (86), 59-69.

[31] Nieto G., Ros G.: Modification of fatty acid composition in meat through diet: Effect on lipid peroxidation and relationship to nutritional quality - A review. In : Lipid Peroxidation. Ed. A. Catala. IntechOpen, London 2012, pp. 230-258.

[32] Olmedilla-Alonso B., Jiménez-Colmenero F., Sánchez-Muniz F.J.: Development and assessment of healthy properties of meat and meat products designed as functional foods. Meat Sci., 2013, 95 (4), 919-930.

[33] Orkusz A.: Czynniki kształtujące jakość mięsa drobiu grzebiącego. Praca przeglądowa. Nauki Inż. Technol., 2015, 1 (16), 47-60.

[34] Osek M., Wasiłowski Z., Janocha A.: Wpływ różnych olejów roślinnych na skład podstawowy i profil kwasów tłuszczowych mięsa kurcząt brojlerów. Rocz. Nauk. Zoot., 2004, 20 Supl., 235- 238.

[35] Osek M., Milczarek A., Janocha A., Turyk Z.: Jakość mięsa kurcząt brojlerów żywionych mieszankami z olejem lnianym i różnym dodatkiem witaminy E. Rocz. IPMiTł, 2006, XIV (1), 207-216.

[36] Osek M., Milczarek A., Janocha A.: Wpływ różnych proporcji oleju sojowego i lnianego w mieszankach dla kurcząt brojlerów na ich wzrost, wartość tuszki i cechy jakościowe mięsa. Rośliny Oleiste, 2008, XXIX, 255-266.

[37] Pietrzak D., Mroczek J., Leśnik E., Świerczewska E.: Jakość mięsa i tłuszczu kurcząt trzech linii hodowlanych żywionych paszą bez lub z dodatkiem antybiotykowego stymulatora wzrostu. Med. Weter., 2006, 62 (8), 917-921.

[38] Pikul J.: Lipidy mięsa drobiowego. W: Przetwórstwo mięsa drobiu - podstawy biologiczne i technologiczne. Red. W. Kopeć i T. Smolińska. Wyd. UP we Wrocławiu, Wrocław 2009, ss. 149-178.

[39] Pisulewski P.W.: Nutritional potential for improving meat quality in poultry. Anim. Sci. Pap. Rep., 2005, 4 (23), 303-315.

[40] Pomianowski J., Wójcik A., Sowińska J., Mituniewicz T., Witkowska D., Chorąży Ł., Kwiatkowska-Stenzel A.: Wartość odżywcza mięsa kurcząt brojlerów transportowanych na różne odległości. Inż. Ap. Chem., 2011, 50 (3), 67-68.

[41] Makała H. (Red.): Sprawozdanie z pracy statutowej: Studia nad jakością, strukturą i właściwościami produktów spożywczych pochodzenia zwierzęcego o podwyższonej wartości żywieniowej. Materiały niepublikowane. Archiwum biblioteki IBPRS. Warszawa 2012.

[42] PN-ISO 1442:2000. Mięso i przetwory mięsne. Oznaczanie zawartości wody (metoda odwoławcza).

[43] PN-ISO 1444:2000. Mięso i przetwory mięsne. Oznaczanie zawartości tłuszczu wolnego.

[44] PN-ISO 936:2000. Mięso i przetwory mięsne. Oznaczanie popiołu całkowitego.

[45] PN-EN ISO 8968-1:2014-03. Mleko i przetwory mleczne. Oznaczanie zawartości azotu. Część 1: Zasada Kjeldahla i obliczanie białka surowego.

[46] PN-ISO 3496:2000. Mięso i przetwory mięsne. Oznaczanie zawartości hydroksyproliny.

[47] PN-EN ISO 12966-2:2017-05. Oleje i tłuszcze roślinne oraz zwierzęce. Chromatografia gazowa estrów metylowych kwasów thuszczowych. Część 2: Przygotowanie estrów metylowych kwasów thuszczowych. 
[48] Sacks F.: The Nutrition Source. Ask the Expert: Omega-3 Fatty Acids: An Essential Contribution, 2008. [on line]. Dostęp w Internecie [22.06.2018]: http://www.hsph.harvard.edu/ nutritionsource/questions/omega-3

[49] Schneiderová D., Zelenka J., Mrkvicová E.: Poultry meat production as a functional food with a voluntary n-6 and n-3 polyunsaturated fatty acids ratio. Czech J. Anim. Sci., 2007, 7 (52), 203-213.

[50] Simopoulos A.P.: An increase in the $\omega-6 / \omega-3$ fatty acid ratio increases the risk for obesity. Nutrients, 2016, 8 (3), 128-138.

[51] Schmitz G., Ecker J.: The opposing effects of $n-3$ and $n-6$ fatty acids. Prog. Lipid Res., 2008, 47 (2), 147-155.

[52] Wood J.D., Richardson R.I., Nute G.R., Fisher A.V., Campo M.M., Kasapidou E., Sheard P.R., Enser M.: Effects of fatty acids on meat quality. Meat Sci., 2004, 66, 21-32.

[53] Zdanowska-Sąsiadek Ż., Michalczuk M., Marcinkowska-Lesiak M., Damiziak K.: Czynniki kształtujące cechy sensoryczne mięsa drobiowego. Bromat. Chem. Tosykol., 2013, XLVI (3), 344-353.

[54] Zelenka J., Schneiderová D., Mrkvicová E.: Linseed oils with different fatty acid patterns in the diet of broiler chickens. Czech J. Anim. Sci., 2006, 51 (3), 117-121.

[55] Žlender B., Holcman A., Stibilj V., Polak T.: Fatty acid composition of poultry meat from free range Reading. AGRIS Sci., 2012, 6, 1-4.

\title{
EFFECT OF FEEDING BOILER CHICKENS WITH FODDER WITH AND WITHOUT FLAX SEEDS ADDED ON SELECTED QUALITY CHARACTERISTICS OF MEAT AND FAT
}

\author{
$\mathrm{S} u \mathrm{~mm}$ a r y
}

The objective of the research study was to assess the effect of feeding broiler chickens with fodder with and without flax seeds added on the selected quality factors of poultry meat and fat. The experimental material consisted of Ross 308 broiler chickens. The chickens were randomly divided into two groups. The one group was fed with the fodder without shot flax seeds added and the other group with the fodder without this additive. The assessment of poultry raw material included: body weight gains of the chickens in the control and experimental groups after the completed rearing; slaughter analysis; $\mathrm{pH}$ value of the femoral and pectoral muscles; profile of discoloration parameters of the pectoral muscle and thigh of chickens using a CIE L $* a * b *$ system; determination of the basic chemical ingredients, such as: water, proteins, fats, minerals in the form of ash and collagen, assessment of the nutritional value based on the lipid profile of breast and thigh muscles and of skins, and subcutaneous and abdominal fat. Based on the results of the experiments performed, it was found that the flax seeds used to feed broiler chickens affected neither the increase in the weight gain nor the increase in the breast and thigh muscle weight of carcass. It was found that feeding with flax seeds affected the increase in the protein content and the reduction in the fat content in the breast and femoral muscles. It was reported that the application of fodder with crushed flax seeds to feed broiler chickens had a beneficial effect on the nutritional value of raw material and on the lipid profile improvement, especially on the higher KT content from the $n$-3 PUFA group and the PUFA $n$-6/PUFA $n-3$ ratio was twice more beneficial. The chicken meat enriched with the $n-3$ fatty acids can be recommended as a source that enriches the diet of people with those acids, i.e. as a functional food.

Key words: broiler chickens, flax seeds, feed enrichment, quality factors of meat and fat 